\title{
Tourism and COVID-19: changes in travel patterns and tourists' behavior in Iran
}

\author{
Roozbeh Mirzaei, Maryam Sadin and Motahareh Pedram
}

\begin{abstract}
Purpose - This paper aims to investigate the changes in travel patterns and tourist behavior due to the COVID-19 outbreak. This study realizes these changes and reports them to help restore tourism.

Design/methodology/approach - This applied study used library sources and a survey conducted through an online questionnaire. The questionnaire incorporated data from previous studies and the most recent online databases. Items were exploratory factors analyzed using the principal component method and varimax rotation. The interpretation of the data collected was consistent with the attributes the questionnaire was designed to measure.

Findings - The research findings show that health and safety have come to the forefront of travelers' needs. The hygiene and disinfection of tourism facilities have changed from hygiene factors to motivator factors. The extended length of trips is perceived as a risk to their health; hence travelers prefer to take shorter trips. They also rather get help from professionals to book their trips.

Research limitations/implications - This research was conducted only in Iran, where travel restrictions were periodically put on and removed. If this study could be conducted in countries with no domestic travel restrictions, other valuable findings such as changes in consumer spending and preferences toward travelling and safety could be found.

Practical implications - This paper provides information on the latest changes to travel patterns and tourists' behavior which can be implied by DMOs (Destination Marketing Organization), governments and private tour operators to understand and consider travelers emerging needs.

Originality/value - This paper enables better planning and organization for the future and restart of tourism post-COVID-19.
\end{abstract}

Keywords COVID-19, Travel pattern, Tourists' behavior, Crisis, Iran

Paper type Research paper

\section{Introduction}

In mid-December 2019, a novel and infectious Coronavirus (COVID-19) struck Wuhan, the most populous city in central China (Yang et al., 2020). Then on January 31, 2020, the World Health Organization (WHO) declared COVID-19 a public health emergency of international concern (WHO, 2020a).

The virus is similar to the severe acute respiratory syndrome (SARS) that emerged in 2003; COVID-19 is an airborne illness that is highly transmittable between humans (Yang et al., 2020), which was found in wild animals that sparked a global pandemic (Liu and Saif, 2020; Yang et al., 2020). To date (January 9, 2021), more than 89.451.806 COVID-19 cases have been reported across 213 countries and territories, and roughly 1.924.037 people have died from the disease (Worldometer, 2021).

The tourism industry has long been recognized as one of the most vulnerable sectors to crises or disasters. In the last 15 years, many health-related crises, especially epidemics, have led to severe damage to the tourism industry at regional or international levels, such as SARS, Ebola and Foot
Roozbeh Mirzaei is based at the University of Mazandaran, Babolsar, Islamic Republic of Iran and Geography, University of Giessen, Giessen, Germany. Maryam Sadin and Motahareh Pedram are both based at the University of Mazandaran, Babolsar, Islamic Republic of Iran.
Received 9 January 2021 Accepted 24 June 2021

(C) Roozbeh Mirzaei, Maryam Sadin and Motahareh Pedram. Published in Journal of Tourism Futures. Published by Emerald Publishing Limited. This article is published under the Creative Commons Attribution (CC BY 4.0) licence. Anyone may reproduce, distribute, translate and create derivative works of this article (for both commercial and non-commercial purposes), subject to full attribution to the original publication and authors. The full terms of this licence may be seen at http://

creativecommons.org/licences/ by/4.0/legalcode

Conflict of interest: The authors reported no potential conflict of interest. 
and Mouth Disease (Yu et al., 2020). Yet, none have had similar implications for the global economy as the COVID-19 pandemic (Gössling et al., 2020). Without a doubt, the tourism sector will experience one of the first and probably most serious shocks caused by the international spread of the COVID-19 outbreak (Mariolis et al., 2020). COVID-19 has caused tremendous damage to the global travel industry. Meanwhile, international tourism has been dramatically affected due to travel restrictions imposed by many countries (UNWTO, 2020a).

According to the United Nations specialized agency, the crisis could lead to international tourist arrivals declined $70 \%$ in the first eight months of 2020 (UNWTO, 2020b). It means tourism has been struck with millions of jobs at risk in one of the economy's most labor-intensive sectors. Considering past market trends, this would mean that between five and seven years' worth of growth will be lost to COVID-19 (Ibid, 2020).

Although numerous studies have been conducted on the impact of crises on tourism and tourist behavior, the epidemics have been limited to a specific geographical area. Such as SARS in southeast Asia, Ebola in Africa and plaque in the Democratic Republic of Congo, which practically affected a particular geographic area for a limited period. Whereas an epidemic in this scale, affecting tourism markets and tourism destinations significantly, has occurred for the first time.

However, nature, the unprecedented circumstances, and the impacts of the COVID-19 demonstrate signs that this crisis is not only different, but it can have profound and long-term structural and transformational changes to tourism as a socio-economic activity (Sigala, 2020). As a result of the COVID-19 outbreak, domestic and international tourism have been widely affected worldwide. Therefore, travelling patterns and tourist behavior have also been affected.

It is also essential to study tourism crisis management in developing countries. The impact of crises can be devastating for the tourism sector in such countries due to being highly reliant on tourism receipts (Novelli et al., 2018). Furthermore, managing the recovery following a tourism crisis is likely to be impaired by the state of fragility associated with developing countries compared to developed countries (lbid, 2018).

We choose Iran because it was one of the first countries to become involved with COVID-19 disease, and its travel and tourism sector was rapidly affected. Also, Iran was among the first countries to lift restrictions against travel. Being concurrent with the Iranian traditional Nowruz festival and Iranian New Year holidays, in mid-March, the most popular travel time, the outbreak was intensified. Iran has suffered the worst coronavirus outbreak in the Middle East, forcing it to impose a lockdown (BBC, 2020). Also, Iran was among the first countries after China to lift restrictions on Saturday, April 11, 2020 (Vahdat, 2020).

Three months after removing the travel restrictions in Iran, it is appropriate to investigate changes in tourist behavior and travel pattern caused by the COVID-19 outbreak. As of now, no study has been conducted on tourists' responses to these changes. Hence, this study's primary aim is to fill this gap by analyzing travel patterns and tourist behavior after the COVID-19 outbreak, investigating its effects on tourists' behavioral changes and comparing it with before the COVID-19 outbreak.

\section{Literature review}

\section{Consumer behavior}

Consumer behavior in tourism remains one of the most researched areas in the marketing and tourism fields, with the terms "travel behavior" or "tourist behavior" typically used to describe this area of inquiry (Cohen et al., 2013). Consumer behavior in the arena of hospitality and tourism studies deals with guests' and tourists' consumption behavior, including pre-visit, on-site and post-visit of the tourists to a particular destination (Dixit et al., 2019). Constraints in tourism behavior consist of interpersonal such as stress, depression and religiosity; after overcoming such constraints, one may face structural constraints (Hudson and Gilbert, 2000). 
There are also a set of factors stimulated by the external circumstances in the environment surrounding the consumer (Mansoor and Jalal, 2010). Perceived risk is also a key consideration when choosing a tourism destination (Perpiña et al., 2020). So perceptions of risk and feelings of safety during travel appear to have a more substantial influence on the avoidance of regions rather than a likelihood of travel to them (Sönmez and Graefe, 1998). It reflects that destination-specific features and the structural characteristics of origin markets can substantially impact the dynamics of tourists' decision-making processes (Choi et al., 2011).

\section{Crisis in tourism}

Undoubtedly, the tourism industry is one of the most susceptible and vulnerable industries to crises; it means that crises are not new to the tourism industry (Santasa, 2008). The tourism crisis is described as circumstances in which tourists and members of it individually or collectively, including destinations, face change potentially destructive for every or certain parties (Henderson, 2007).

It has become clear that significant natural and human-induced phenomena can significantly influence tourism growth and development (Mason et al., 2005). Short duration, episodic events, such as epidemic diseases, natural disasters, civil strife and economic crises, can negatively affect tourism development in the short or long term (Zeng et al., 2005). Some of the industry's crises are natural disasters, terrorist attacks, economic crises and disease. Health issues, particularly those related to contagious diseases and international epidemics, have significantly impacted the tourism industry (Monterrubio, 2010). Epidemic infections and their severe social and economic implications have caused, under certain conditions, devastating results in the tourism industry (Mason et al., 2005). Although numerous health-related crises have happened over the years, no crisis certainly had a catastrophic impact like the COVID-19 outbreak on the tourism sector (Sigala, 2020).

\section{Tourism and pandemics}

Pandemics are not exactly a novel phenomenon strictly related to modern societies as they were recorded since ancient times (Butu et al., 2020). Clearly, a pandemic is defined as the worldwide spread of a new disease [. . . [against which] most people do not have immunity (WHO, 2010).

As a brief reminder about pandemics is three influenza pandemics occurred at intervals of several decades during the 20th century, the most severe of which was the so-called "Spanish Flu" (caused by an A(H1N1) virus), which estimated to have caused 20-50 million deaths in 1918-1919 (WHO, 2020b). The great influenza pandemic arose in three primary waves, the first in spring 1918, the second and deadliest from September 1918 to January 1919 and the third from February 1919 to June 1920 (Barro et al., 2020). Milder pandemics occurred subsequently in 1957-1958 (the "Asian Flu") and in 1968 (the "Hong Kong Flu"), which were estimated to have caused one to four million deaths each (WHO, 2020b).

Among the recent year's epidemics is the H5N1 Avian Influenza (hereafter Avian Flu) epidemic, received worldwide attention since 2004, which were initially detected in East and South-East Asia and were subsequently spread worldwide (Chan and Baum, 2007).

The first influenza pandemic of the 21st century was caused by an influenza A ( $\mathrm{H} 1 \mathrm{~N} 1)$ virus ( $\mathrm{WHO}$, 2020b). The initial outbreak occurred in Mexico in March 2009 before spreading to coterminous countries in the Americas and then to countries further afield. However, the world was not entirely unprepared for the swine flu crisis, given the WHO's preparations in 2005 and 2006 to anticipate a possible avian flu outbreak. Still, most countries felt its effects by December 2009, although its severity and scale varied by region (Page et al., 2011).

Amid the various infectious disease epidemics which have affected the tourism industry, there is the Severe Acute Respiratory Syndrome (hereafter SARS) epidemic. SARS first started in Guangdong Province, China, in December 2002 and lasted for about half a year, affecting 26

VOL. 9 NO. 12023 JOURNAL OF TOURISM FUTURES $\mid$ PAGE 51 
provinces and cities in China, including Beijing, Hebei, Inner Mongolia and neighboring countries (Wen et al., 2005). China's tourism, which appeared to have had a good start in 2003, received a severe strike from March to July (lbid, 2005).

\section{Tourism and COVID-19}

The novel coronavirus outbreak has attracted researchers' attention from all disciplines worldwide. Tourism-related articles discuss topics such as pandemics, tourism and global change, transformations, socializing tourism and the impact of travel restrictions on the spread of the COVID-19 outbreak (Gössling et al., 2020; Hall et al., 2020; Higgins-Desbiolles, 2020; Hoque et al., 2020; Chinazzi et al., 2020; Zheng et al., 2020).

The COVID-19 pandemic is considered the most crucial global health calamity of the century and the most significant challenge humankind faced since the Second World War (Chakraborty and Maity, 2020). The closest parallel to the situation we are in now could be the Spanish flu in 1918, estimated to have infected about $27 \%$ and killed about $1.7 \%$ of the world's population.

The closest comparison to the COVID-19 outbreak can be the SARS epidemic. Yet, the greater geographical scale of the COVID-19 pandemic and the number of reported cases should be considered while comparing the two. Dutton (2020) compares these two pandemics. Both pandemics have similar symptoms such as high fever, cough and shortness of breath. They also have identical origins; initially, SARS and COVID-19 viruses both jumped from animals to humans. At the same time, the transmission of the coronavirus is also person to person and through droplets. Both viruses were utterly new to humans and had no vaccines or therapeutics when reported. The SARS pandemic was short-lived. Only eight months separated the first reported case to the end of July 2003. Equitable access to safe and effective vaccines is critical to ending the COVID-19 pandemic (WHO, 2019) and till date, numerous vaccines have been developed and approved (WHO, 2020c). In many countries, the vaccination process has started and developed and other countries have been quick to follow. It appears so that with the given situation, countries will soon start to reopen their borders to tourism (Schengenvisainfo news, 2021).

The near-complete lockdown imposed in response to the pandemic led to an $81 \%$ fall in international tourist numbers in July and 79\% in August compared to 2019. The drop until August represents 700 million fewer arrivals and translates into a loss of US\$ 730bn in export revenues from international tourism (UNWTO, 2020b).

Some countries are predicted to face more substantial blows than others due to their high reliance on the sector. Especially when considering a comparison: out of the top 10 destinations by international tourists' arrivals (France, Spain, the USA, China, Italy, Turkey, Mexico, Germany, UK and Thailand), eight results to be the hardest hit by COVID-19, implying that the economic shock on tourism will be further exacerbated in these countries (Maniga, 2020).

Most UNWTO Panel Experts expect a rebound in international tourism by the third quarter of 2021 and a return to pre-pandemic 2019 levels not before 2023 (UNWTO, 2020b). The pandemic will probably have a longer-lasting effect on international tourism due to reduced consumer confidence. According to the World Travel and Tourism Council, in previous viral epidemics, visitors' average recovery time to a destination was about 19 months (Hamilton, 2020).

Gössling et al. (2020) conducted a rapid assessment of COVID-19. They compared the impacts of COVID-19 to previous epidemics/pandemics and other types of global crises and explored how the pandemic may change society, the economy and tourism. In another study (Hall et al., 2020), a comprehensive review of previous pandemics is provided and used to help contextualize the COVID-19 pandemic, its impact on tourism and government, industry and consumer response. It is concluded that the selective nature of the effects of COVID-19 and the measures to contain it may lead to a reorientation of tourism in some cases, but in others will contribute to policies reflecting the selfish nationalism of some countries.

PAGE 52 JOURNAL OF TOURISM FUTURES $\mid$ VOL. 9 NO. 12023 
Also, countries around the world have reacted quickly to the spread of the coronavirus. Governments have imposed certain restrictions and bans to protect their nation. National administrations rapidly realized that travel ease is a primary factor facilitating the outbreak (Niewiadomski, 2020). Most countries responded with various non-pharmaceutical interventions, including lockdown, social distancing, closure of schools/universities and non-essential businesses/workplaces, canceling or postponing events and bans gatherings of people over specific numbers (Gössling et al., 2020).

The European Commission proposed to suspend the rules obliging airlines to use their allocated slots at EU airports. It also gave guidelines on EU passenger rights and border checks and recommended the member states to restrict non-essential travel to the EU for 30 days (European Parliament, 2020). Thus, the pandemic triggered a significant change in economics, regional and global policies, social behavior and citizens' mentalities (Butu et al., 2020).

\section{Research methodology}

The required data for this applied research were collected using two methods, library and survey done by online questionnaires. Incorporating all data from previous studies and online databases, a questionnaire in two parts, consisting of 43 statements, was prepared. It consisted of 43 items which were designed based on Likert's 5 -point scale from 1 ("not important at all") to 5 ("extremely important"), 1 ("very unlikely") to 5 ("very likely") and 1("Strongly agree") to 5 ("strongly disagree"). A sample of 150 respondents was chosen to pretest and assess the questionnaire's content validity and respondents' understanding of questions. Some changes were made regarding the wording of questions, elimination and changing of some questions and their order to make the questionnaire more understandable. The final questionnaire was then sent to respondents via email or social media like Telegram, WhatsApp, Instagram and Facebook.

Respondents from Iran were asked to fill the questionnaire if they met two prerequisites. First, they must have traveled during the previous year (before the pandemic), and second, they traveled after lifting the coronavirus pandemic restrictions in Iran at the end of April. Respondents were also asked to forward it to people who also met the requirements. Altogether, 2,250 questionnaires were sent via the previously mentioned portals. A total number of 1,245 questionnaires were collected during the first half of August 2020. After discarding incomplete questionnaires, the number of 1,001 complete questionnaires were analyzed. Items were an exploratory factor analyzed using the principal component method and varimax rotation (Fabrigar et al., 1999), 17 variables with loading less than 0.50 were removed.

The Kaiser-Meyer-Oklin measure was 0.802, which is good or "meritorious" on Kaiser's (1974) classification of measure values. Bartlett's test of sphericity was statistically significant $(p<0.0005)$, indicating that the data was likely factorizable. The reliability coefficient was obtained using Cronbach's alpha method equal to 0.755 , meaning that it had good reliability.

Visual inspection of the scree plot indicated that six components should be retained (Cattell, 1966). The varimax orthogonal rotation was used to aid interpretability, and the rotated solution exhibited "simple structure" (Thurstone, 1947). The interpretation of the data was consistent with the attributes the questionnaire was designed to measure. Principal Component Analysis (PCA) revealed six components that had eigenvalues greater than one, which explained $11.09 \%$, $10.96 \%, 10.17 \%, 9.14 \%, 6.90 \%$ and $6.8 \%$ of the total variance, respectively, and $55.09 \%$ of the total variance. All the factors have an eigenvalue more than one and have at least three items.

Six factors were named: social distancing and hygiene, COVID-19 and choices, disinfection of tourism facilities, COVID-19 and health concerns, COVID-19 and familiarity, COVID-19 and travel preferences. Cronbach's alpha calculated the stability of each factor too.

\section{Results and discussion}

Sociodemographic characteristics of the respondents show the ratio of respondents is more female than male. Most respondents are young aged between 31 and 40 years. Among the 
respondents, $52.5 \%$ possessed a bachelor's degree, and 19.3\% had a master's degree (Table 1).

The results show that accommodation facilities' hygiene and disinfection are essential for tourists traveling during the COVID-19 outbreak (mean $=4.62$ ). Also, the importance of the destination's health and hygiene system is relatively high (mean $=4.40$ ). Concerning hygiene and safety before the COVID-19 outbreak, data reveal that hygiene and disinfection of accommodation facilities before COVID-19 were remarkable (mean $=4.10$ ). It is observed that health-related components are of great importance based on respondents' views. During a pandemic, health is the most critical issue globally, and governments worldwide strive to improve it and raise tourists' level of satisfaction.

The hygiene of accommodation facilities has been an essential component in the tourism sector for many years, and it is clear that it has not lost its importance. COVID-19 outbreak has become a crucial issue for travelers and tourism service providers; thus, following health-related guidelines will result in safer travel. Visitors prefer to choose a destination where they do not need to worry about their health and safety. Therefore, they would travel to destinations where COVID-19 has not spread widely or has not been marked as dangerous by governmental health authorities.

During the first weeks of the COVID-19 outbreak and being concurrent with the Iranian New Year and Nowruz holidays, many people traveled despite the government's warning. At such times, tourists prefer to avoid public transportation and use their cars, choosing destinations within driving distance. Traveling to an area with a high number of reported cases or a destination with fewer facilities might not be wise. Therefore, tourists somewhat change their previous choices and travel to other destinations. As a more extended stay in new surroundings may expose tourists to more dangers, they prefer shorter trips.

Table 2 shows the specific items of each factor used in this study, together with their standardized factor loading values. The correlation coefficient above 0.5 was considered initial (Hair et al., 1998). All factor loadings were equal to or higher than 0.477 , and all were significant at the $p=0.001$ levels. Factors explained a total variance of around 55.09\% (Table 2).

Social distancing and hygiene with a variance of $11.09 \%$ and reliability coefficient of 0.773 , including five items, is factor one, which refers to two main aspects of the tourist's behavior; hygiene and disinfection of tourism facilities and social distancing in tourist destinations. The importance of hygiene in tourism destinations has long been considered as one of the most critical factors in choosing a destination and its image from tourists' perspective (Dolnicar, 2004, p.16;

\begin{tabular}{lrrlrr}
$\begin{array}{l}\text { Table 1 } \\
\text { Variable }\end{array}$ & Sample & $\%$ & Variable & Sample & $\%$ \\
\hline Gender & & & Occupation & \\
Female & 629 & 62.8 & Retired & 134 & 13.4 \\
Male & 372 & 37.2 & Researcher & 21 & 2.1 \\
Age & & & Student & 172 & 17.2 \\
Under 20 & 39 & 3.9 & Freelance job & 104 & 10.4 \\
$20-31$ & 324 & 32.4 & Health care staff & 123 & 12.3 \\
$31-40$ & 393 & 39.3 & Worker & 8 & 0.8 \\
$41-50$ & 183 & 18.3 & Employee & 96 & 9.6 \\
$51-60$ & 55 & 5.5 & Farmer & 42 & 4.2 \\
More than 61 & 7 & 0.7 & Teacher/Lecturer & 132 & 13.2 \\
Education & & & Other occupations & 169 & 16.9 \\
High school & 24 & 2.4 & & & \\
Vocational school/Associate degree & 147 & 14.7 & & & \\
Bachelor's degree & 526 & 52.5 & & & \\
Master's degree & 193 & 19.3 & & &
\end{tabular}

PAGE 54 |JOURNAL OF TOURISM FUTURES $\mid$ VOL. 9 NO. 12023 
Table 2 Principal components analysis of the research items $(N=1,001)$

\begin{tabular}{|c|c|c|c|c|c|c|c|}
\hline Factors & Item & $F 1$ & $F 2$ & F3 & F4 & F5 & F6 \\
\hline Factor 1 & Hygiene and disinfection of accommodation facilities & 0.765 & & & & & \\
\hline \multirow{4}{*}{$\begin{array}{l}\text { Social distancing and } \\
\text { hygiene }\end{array}$} & Hygiene and disinfection of tourism and recreation facilities & 0.745 & & & & & \\
\hline & Social distancing in destination & 0.716 & & & & & \\
\hline & Hygiene and disinfection of transportation facilities & 0.690 & & & & & \\
\hline & Destination's health and hygiene system & 0.673 & & & & & \\
\hline Factor 2 & I would choose airlines that offer special discounts & & 0.770 & & & & \\
\hline \multirow{5}{*}{$\begin{array}{l}\text { COVID-19 and } \\
\text { choices }\end{array}$} & I would choose hotels which offer special discounts & & 0.709 & & & & \\
\hline & $\begin{array}{l}\text { I would choose destinations/places which I got familiar with } \\
\text { through virtual tours }\end{array}$ & & 0.623 & & & & \\
\hline & I would travel on a plane & & 0.619 & & & & \\
\hline & $\begin{array}{l}\text { I would seek the help of travel agencies for my travel } \\
\text { arrangements }\end{array}$ & & 0.605 & & & & \\
\hline & I would choose a destination where offers special discounts & & 0.528 & & & & \\
\hline \multirow{5}{*}{$\begin{array}{l}\text { Factor } 3 \\
\text { Disinfection of } \\
\text { facilities }\end{array}$} & Hygiene and disinfection of tourism and recreation facilities before & & & 0.860 & & & \\
\hline & COVID-19 & & & & & & \\
\hline & $\begin{array}{l}\text { Hygiene and disinfection of transportation facilities before } \\
\text { COVID-19 }\end{array}$ & & & 0.813 & & & \\
\hline & Destination's health and hygiene system before COVID-19 & & & 0.797 & & & \\
\hline & $\begin{array}{l}\text { Hygiene and disinfection of accommodation facilities before } \\
\text { COVID-19 }\end{array}$ & & & 0.731 & & & \\
\hline $\begin{array}{l}\text { Factor } 4 \\
\text { COVID-19 and health }\end{array}$ & $\begin{array}{l}\text { I would choose hotels and restaurants that publish their health } \\
\text { and hygiene processes to ensure consumers }\end{array}$ & & & & 0.711 & & \\
\hline \multirow[t]{4}{*}{ concerns } & $\begin{array}{l}\text { I would choose a destination where I do not have to worry about } \\
\text { the spread of COVID-19 and related health issues }\end{array}$ & & & & 0.710 & & \\
\hline & $\begin{array}{l}\text { I would choose destinations that follow corona-related health } \\
\text { guidelines }\end{array}$ & & & & 0.709 & & \\
\hline & I would bring my dishes and blanket during the trip & & & & 0.504 & & \\
\hline & I would follow social distancing guidelines while visiting attractions & & & & 0.477 & & \\
\hline Factor 5 & I would choose a destination in which I have friends or relatives & & & & & 0.720 & \\
\hline COVID-19 and & I would travel to a destination nearby (I can drive there by car) & & & & & 0.608 & \\
\hline familiarity & I would choose a familiar destination & & & & & 0.601 & \\
\hline $\begin{array}{l}\text { Factor } 6 \\
\text { COVID-19 and }\end{array}$ & $\begin{array}{l}\text { The COVID- } 19 \text { outbreak has made me choose another } \\
\text { destination }\end{array}$ & & & & & & 0.803 \\
\hline preferences & The COVID-19 outbreak made me have shorter trips & & & & & & 0.750 \\
\hline & The COVID-19 outbreak has made me reluctant to travel at all & & & & & & 0.573 \\
\hline Cronbach's alpha & & 0.773 & 0.780 & 0.797 & 0.634 & 0.530 & 0.658 \\
\hline
\end{tabular}

Note(s): Rotation: Varimax with Kaiser normalization; percentage of variance extracted: $55.09 \%$

Chan and Baum, 2007; Swarbrooke and Horner, 2007; Kayar and Kozak, 2010; Jovanović et al., 2015; Naumov et al., 2020).

However, following social distancing rules is a new variable that was previously only considered in terms of personal space, and after the COVID-19 outbreak, it is being considered in terms of keeping a safe distance to avoid transmission of the virus. This has led to some constraints in managing tourism destinations, particularly in determining the maximum number of visitors in a given time or visitation time limits. Thus, safety and hygiene are a top priority for travelers.

The next factor is COVID-19 and choices with a variance of $10.96 \%$ and the reliability coefficient of 0.780 , which includes six items. This factor refers to the selection of services in tourism destinations. Hence, offering special discounts and packages related to the destination's services is essential, according to the tourists' opinions. It should be highlighted that these offers do not affect the destination choice as much as the choice of services provided at destinations. As the COVID-19 crisis has hit the tourism economy hard, even for travelers and destinations, some research shows that many consumers use special promotional deals that contrast with this statement (Correia and Crouch, 2004). Consumers may choose to travel to a destination, mainly when there is a competitive discount package (Rewtrakunphaiboon and Oppewal, 2004). 
The disinfection of tourism facilities with a variance of $10.17 \%$ and reliability coefficient of 0.797 , consisting of four items, is related to the importance of the hygiene and disinfection of tourism facilities before the COVID-19 outbreak. As mentioned before, hygiene has always been an essential factor in choosing a destination, especially services offered in accommodation facilities, restaurants and tourism attractions. This factor has been emphasized as a determining factor in choosing a destination in many previous studies (Lockyer, 2003; Ryan and Huimin, 2007; Tsai et al., 2009; Ramanathan and Ramanathan, 2013; Amblee, 2015; Zemke et al., 2015; Alananzeh, 2017).

The COVID-19 and health concern, factor four with a variance of $9.14 \%$ and a reliability coefficient of 0.634 consists of five items. This factor's implication is associated with the role of compliance with health protocols related to COVID-19 in choosing a destination and tourism services. As we know, health and safety during traveling have been a long-discussed topic for the tourism industry, which has become more critical during the outbreak. So, the intersection between health concerns and travel is especially apparent during disease outbreaks.

Compliance with protocols in a tangible way for tourists to observe has a significant role in selecting a destination and tourism service providers in the destination. Health and hygiene are the core of concern in COVID-19. Understanding tourist behavior during and after major tourism crises is essential to help destinations recover. The COVID-19 pandemic, a period of uncertainty and risk, makes it relevant to assess factors that influence travel intentions. Destination management measures in coping with COVID-19, the number of deaths and countries' overall performance in dealing with COVID-19 can be assessed in this framework. The relationships between pandemics and travel are central to understanding health security and global change too.

Also, COVID-19 and familiarity, which consists of three items, is factor five with a $6.90 \%$ variance and reliability coefficient of 0.530 . Prior familiarity with destinations leads to being ensured about the provision of reliable services for tourists. According to this, after the COVID-19 outbreak, tourists prefer to choose nearby destinations that can be reached within driving distance using their vehicles. It means the COVID-19 pandemic is changing the way of traveling. Some research shows that people will avoid public transport and use personal cars to travel shorter distances (Devos, 2020). Thus, the usage of private vehicles ensures compliance with health and hygiene-related protocols. Moreover, tourists are not obligated to wear a mask.

The end factor (six) is COVID-19 and travel preferences with a variance of $6.8 \%$ and a reliability coefficient of 0.658 , which includes three items. This factor is attributed to the effect of the COVID19 outbreak in choosing a closer destination. The newly set restrictions and limits in international travel, cancellation of flights and hygiene concerns will be more in traveling to farther destinations, resulting in tourists selecting local and closer destinations.

\section{Discussion and Conclusion}

Like any other pandemics, COVID-19 has caused significant changes in all states, continents, regions, urban and rural communities, families; and ultimately, each individual's thinking and lifestyle have been impacted by the pandemic (Butu et al., 2020). Domestic and international flights have been stopped in most countries, and travel restrictions put in place have made tourism and even traveling for essential reasons scarce.

Most businesses related to tourism, such as accommodation facilities, restaurants and travel agencies, are shut down or operate with limited capacities, such as airlines. This has led to uncertainty, followed by an unwillingness to travel even after restrictions are being eased. Due to COVID-19; travelers' behaviors, demands and even their attributes to travel had changed. Identifying consumers' behavior change, particularly in destination and service choice, is vital in rebuilding tourists' lost trust and reviving tourism. Thus, this research has analyzed the change in tourists' behavioral patterns due to the COVID-19 outbreak and compared it with the prepandemic conditions. 
This study has identified six main factors: social distancing and hygiene, COVID-19 and choices, disinfection of tourism facilities, COVID-19 and health concerns, COVID-19 and familiarity, COVID19 and travel preferences.

By comparing tourists' preferences before and during the COVID-19 outbreak, it is evident that hygiene and cleanliness of accommodation facilities have been important throughout the time. Tourists attach importance to the hygiene of accommodation establishments, environment and restaurants (Jovanović et al., 2015). It can be stated that hygiene is an essential factor in providing standard services in the sector. Moreover, from the perspective of motivation and what causes behavior, to further explain the findings, Herzberg's two-factor theory, i.e. hygiene factors and motivators, can be used as a theoretical basis.

The absence of hygiene factors will result in customer dissatisfaction, but their mere existence will not necessarily result in a motivated customer (Herzberg et al., 1959). In this case, it can be observed that hygiene and disinfection of tourism facilities have changed from hygiene factors to motivator factors. As if a hotel fails to comply with COVID-19 health-related protocols, and the absence of clear guidelines in such facilities may result in consumer dissatisfaction, such requirements were not questioned before the COVID-19 outbreak. Therefore, when choosing an accommodation service provider, selecting one that follows all health and hygiene-related guidelines act as a motivator factor for tourists who travel during a pandemic.

Destinations must gain tourists' trust and build their confidence by complying with all health and safety regulations and guidelines published by international organizations such as WHO and CDC. Publishing health and hygiene protocols in destinations' and service providers' websites is an appropriate way to inform travelers and ensure that any potential risk to their health is recognized and fought against.

This study's findings showed that compliance with social distancing rules is useful as a new variable concerning the choice of tourism destinations and services provided in these destinations. Before the COVID-19 outbreak, this factor was indirectly found only when a place's physical carrying capacity did not allow more tourists. However, after the COVIID-19 pandemic, keeping a safe distance has been a critical measure to control the virus's spread. This can cause limits on how many people can attend events and gatherings or enter restaurants and bars. Also, the timing of tours, quality of visit, the time available to visit and tourists' peace of mind can be changed. Reducing the physical capacity of different service providers influences the services' pricing strategies. It increases their variable costs, followed by an increase in the services' final price and a decrease in travel demand. Tourists must be informed about attractions visiting hours and capacity at any time.

Destinations are required to regularly publish the number of COVID-19 cases and measures taken to control and contain the virus to have transparency with tourists, which will further lead to tourists' trust and confidence to travel to those destinations. Such measures may include installing thermal cameras at the airports, cleaning airplanes with special disinfectants, monitoring and testing all the staff who work in service areas, installing handwashing stands at destinations and providing disinfecting gels and sprays for visitors at destinations and mandating wearing a mask. Tourists also need to be ensured that the destination has enough health service providing facilities with the highest standards. Thus, destinations need to upgrade and promote their health-care systems and services.

It has become clear that travelers will prefer to seek professional help for traveling during and after the pandemic, requiring all service providers and destinations to focus on marketing services through trusted travel agencies. Such needs call for a comprehensive and transparent collaboration between tourism service providers, destinations and travel agencies.

As illustrated in the results, Visiting Friends and Relatives (VFR) tourism will be at the top of the traveling preferences list. Familiarity with tourism places and destinations have become a 
significant factor in travel during and after the COVID-19 outbreak. This translates to car trips to nearby destinations or, in other words, domestic tourism. Nations can promote domestic tourism and provide required facilities for their citizens. Improvement of road transport infrastructures, railway systems and following health and hygiene protocols in buses and taxis are mandatory to guarantee tourists' safety.

It is an excellent time for destinations to turn their attention towards the usage of technology. The use of Virtual Reality (VR) tours to promote and market tourist attractions and all tourism-related service providers such as hotels and restaurants is recommended. This will give tourists an idea of what to expect when they travel and boost their enthusiasm for traveling. Moving towards a contactless and touchless environment, service providers can use Artificial Intelligence (Al) and robots to deliver services to guests and visitors at hotels, restaurants and attractions. Adopting such up-to-date and state of the art technologies will ensure travelers of the value of their health to governments and tourism organizations in different countries.

\section{References}

Alananzeh, O.A. (2017), "Impact of safety issues and hygiene perceptions on customer satisfaction: a case study of four and five star hotels in Aqaba, Jordan", Journal of Tourism Research and Hospitality, Vol. 06 No. 01, pp. 1-7.

Amblee, N. (2015), "The impact of cleanliness on customer perceptions of security in hostels: a WOM-based approach", International Journal of Hospitality Management, Vol. 49, pp. 37-39.

Barro, R.J., Ursúa, J.F. and Weng, J. (2020), The Coronavirus and the Great Influenza Pandemic: Lessons from the "Spanish Flu" for the Coronavirus's Potential Effects on Mortality and Economic Activity, National Bureau of Economic Research, No. 8166.

BBC (2020), "Coronavirus: Iranians urged to stay home during holiday", available at: www.bbc.com/news/ world-middle-east-51968774 (accessed 19 March 2020).

Butu, A., Bruma, S., Tanasa, L., Rodino, S., Vasiliu, C., Dobos, S. and Butu, M. (2020), "The impact of COVID-19 crisis upon the consumer buying behavior of fresh vegetables directly from local producers", International Journal of Environmental Research and Public Health, Vol. 17 No. 15, p. 5485.

Cattell, R.B. (1966), "The Scree test for the number of factors", Multivariate Behavioral Research, Vol. 1 No. 2, pp. 245-276.

Chakraborty, I. and Maity, P. (2020), "COVID-19 outbreak: migration, effects on society, global environment and prevention", Science of The Total Environment, Vol. 728 No. 138882.

Chan, J.K.L. and Baum, T. (2007), "Determination of satisfiers and dissatisfiers using Herzberg's motivator and hygiene factor theory: an exploratory study", Tourism Culture and Communication, Vol. 7 No. 2, pp. 117-131.

Chinazzi, M., Davis, J.T., Ajelli, M., Gioannini, C., Litvinova, M., Merler, S., .. a and Vespignani, A. (2020), "The effect of travel restrictions on the spread of the 2019 novel coronavirus (COVID-19) outbreak", Science, eaba, 9757.

Cohen, S.A., Prayag, G. and Moital, M. (2013), "Consumer behavior in tourism: concepts, influences and opportunities", Current Issues in Tourism, Vol. 17 No. 10, pp. 872-909.

Correia, A. and Crouch, G.I. (2004), "A study of tourist decision processes: Algarve, Portugal", in Crouch, G.I., Perdue, R.R., Timmermans, H.J.P. and Uysal, M. (Eds), Consumer Psychology of Tourism, Hospitality and Leisure, CABI, Wallingford, pp. 121-134.

Choi, S., Lehto, X.Y., Morrison, A.M. and Jang, S.S. (2011), "Structure of travel planning processes and information use patterns", Journal of Travel Research, Vol. 51 No. 1, pp. 26-40.

Devos, J. (2020), "The effect of COVID-19 and subsequent social distancing on travel behavior", Transportation Research Interdisciplinary Perspectives, Vol. 5 No. 100121.

Dixit, S.K., Lee, K.-H. and Loo, P.T. (2019), "Consumer behavior in hospitality and tourism”, Journal of Global Scholars of Marketing Science, Vol. 29 No. 2, pp. 151-161.

Dolnicar, S. (2004), "Profiling the one- and two-star hotel guests for targeted segmentation action: a descriptive investigation of risk perceptions, expectations, disappointments and information processing 
tendencies", in Crouch, G.I., Perdue, R.R., Timmermans, H.J.P. and Uysal, M. and (Eds), Consumer Psychology of Tourism, Hospitality and Leisure, CABI, pp. 11-19.

Dutton, G. (2020), “Compare: 2003 SARS pandemic versus 2020 COVID-19 pandemic”, available at: www. biospace.com/article/comparison-2003-sars-pandemic-vs-2020-covid-19-pandemic/ (accessed 3 June 2020).

European Parliament (2020), "COVID-19 and the tourism sector", available at: www.europarl.europa.eu/ thinktank/en/document.html?reference=EPRS_ATA\%282020\%29649368 (accessed 6 April 2020).

Fabrigar, L.R., Wegener, D.T., MacCallum, R.C. and Strahan, E.J. (1999), "Evaluating the use of exploratory factor analysis in psychological research", Psychological Methods, Vol. 4, pp. 272-299.

Gössling, S., Scott, D. and Hall, C.M. (2020), "Pandemics, tourism and global change: a rapid assessment of COVID-19", Journal of Sustainable Tourism, Vol. 29 No. 1, pp. 1-20.

Hair, J.F., Black, W.C., Anderson, R.E., Tatham, R.L. and Babin, J.B. (1998), Multivariate Data Analysis a Global Perspective, Pearson, Edinburgh.

Hall, C.M., Scott, D. and Gössling, S. (2020), "Pandemics, transformations and tourism: be careful what you wish for", Tourism Geographies, Vol. 22 No. 3, pp. 577-598.

Hamilton, P.coke (2020), "Impact of COVID-19 on tourism in small island developing states", available at: https://unctad.org/news/impact-covid-19-tourism-small-island-developing-states (accessed 14 April 2020).

Henderson, J.C. (2007), Managing Tourism Crises: Causes, Consequences and Management, Elsevier.

Herzberg, F., Mausner, B. and Snyderman, B.B. (1959), The Motivation to Work, Wiley, New York.

Higgins-Desbiolles, F. (2020), "Socialising tourism for social and ecological justice after COVID-19", Tourism Geographies, Vol. 22 No. 3, pp. 610-623.

Hoque, A., Shikha, F.A., Hasanat, M.W., Arif, I. and Hamid, A.B.A. (2020), "The effect of Coronavirus (COVID-19) in the tourism industry in China", Asian Journal of Multidisciplinary Studies, Vol. 3 No. 1, pp. 52-58.

Hudson, S. and Gilbert, D. (2000), "Tourism constraints: the neglected dimension in consumer behavior research", Journal of Travel and Tourism Marketing, Vol. 8 No. 4, pp. 69-78.

Jovanović, S., Janković-Milić, V. and llić, I. (2015), "Health and hygiene importance for the improvement of tourism sector competitiveness in Serbia and the South-Eastern Europe countries", Procedia Economics and Finance, Vol. 19, pp. 373-382.

Kaiser, H.F. (1974), "An index of factorial simplicity”, Psychometrika, Vol. 39, pp. 31-36.

Kayar, Ç.H. and Kozak, N. (2010), "Measuring destination competitiveness: an application of the travel and tourism competitiveness index (2007)", Journal of Hospitality Marketing and Management, Vol. 19 No. 3, pp. 203-216.

Liu, S.-L. and Saif, L. (2020), "Emerging viruses without borders: the Wuhan coronavirus", Viruses, Vol. 12 No. 2130.

Lockyer, T. (2003), "Hotel cleanliness-how do guests view it? Let us get specific. A New Zealand study", International Journal of Hospitality Management, Vol. 22 No. 3, pp. 297-305.

Maniga, P. (2020), "The impact of COVID-19 on tourism | policy center for the new south", available at: www. policycenter.ma/opinion/impact-covid-19-tourism (accessed 16 June 2020).

Mansoor, D. and Jalal, A. (2010), "The global business crisis and consumer behavior: kingdom of Bahrain as a case study", International Journal of Business and Management, Vol. 6 No. 1.

Mariolis, T., Rodousakis, N. and Soklis, G. (2020), "The COVID-19 multiplier effects of tourism on the Greek economy”, Journal of Tourism Economics, Vol. 6 No. 1, pp. 114-147.

Mason, P., Grabowski, P. and Du, W. (2005), "Severe acute respiratory syndrome, tourism and the media", International Journal of Tourism Research, Vol. 7 No. 1, pp. 11-21.

Monterrubio, J.C. (2010), "Short-term economic impacts of influenza A (H1N1) and government reaction on the Mexican tourism industry: an analysis of the media", International Journal of Tourism Policy, Vol. 3 No. 1.

Naumov, N., Varadzhakova, D. and Naydenov, A. (2020), "Sanitation and hygiene as factors for choosing a place to stay: perceptions of the Bulgarian tourists", Anatolia, pp. 1-4.

VOL. 9 NO. 12023 JOURNAL OF TOURISM FUTURES $\mid$ PAGE 59 
Niewiadomski, P. (2020), "COVID-19: from temporary de-globalisation to a re-discovery of tourism?", Tourism Geographies, Vol. 22 No. 3, pp. 651-656.

Novelli, M., Gussing Burgess, L., Jones, A. and Ritchie, B.W. (2018), “'No Ebola. . .still doomed' - the Ebolainduced tourism crisis", Annals of Tourism Research, Vol. 70, pp. 76-87.

Page, S., Song, H. and Wu, D.C. (2011), "Assessing the impacts of the global economic crisis and swine flu on inbound tourism demand in the United Kingdom", Journal of Travel Research, Vol. 51 No. 2, pp. $142-153$.

Perpiña, L., Prats, L. and Camprubí, R. (2020), “Image and risk perceptions: an integrated approach", Current Issues in Tourism, pp. 1-18.

Ramanathan, U. and Ramanathan, R. (2013), "Investigating the impact of resource capabilities on customer loyalty: a structural equation approach for the UK hotels using online ratings", Journal of Services Marketing, Vol. 27 No. 5, pp. 404-415.

Rewtrakunphaiboon, W. and Oppewal, H. (2004), "Effects of holiday packaging on tourist decision making: some preliminary results", in Crouch, G.I., Perdue, R.R., Timmermans, H.J.P. and Uysal, M. and (Eds), Consumer Psychology of Tourism, Hospitality and Leisure, CABI, pp. 181-188.

Ryan, C. and Huimin, G. (2007), "Perceptions of Chinese hotels", Cornell Hotel and Restaurant Administration Quarterly, Vol. 48 No. 4, pp. 380-391.

Santasa, G. (2008), "Crisis management and tourism", Travel and Tourism Marketing, Vol. 27 No. 4, pp. 299-321.

Schengenvisainfo news (2021), "Timeline of EU member states reopening their borders", available at: https:// www.schengenvisainfo.com/news/timeline-of-eu-member-states-reopening-their-borders/ (accessed 23 May 2021).

Sigala, M. (2020), "Tourism and COVID-19: impacts and implications for advancing and resetting industry and research", Journal of Business Research No. 117, pp. 312-321.

Sönmez, S.F. and Graefe, A.R. (1998), "Determining future travel behavior from past travel experience and perceptions of risk and safety”, Journal of Travel Research, Vol. 37 No. 2, pp. 171-177.

Swarbrooke, J. and Horner, S. (2007), Consumer Behavior in Tourism, 2nd ed., Elsevier.

Thurstone, L.L. (1947), "Multiple-factor analysis", Journal of Clinical Psychology, Vol. 4 No. 2, p. 224.

Tsai, H., Song, H. and Wong, K.K.F. (2009), "Tourism and hotel competitiveness research", Journal of Travel and Tourism Marketing, Vol. 26 No. 5, pp. 522-546.

UNWTO (2020a), "Impact assessment of the COVID-19 outbreak on international tourism", available at: www.unwto.org/impact-assessment-of-the-covid-19-outbreak-on-international-tourism (accessed 15 June 2020).

UNWTO (2020b), "International travel plunges $70 \%$ in the first eight months of 2020 ", available at: www. eunwto.org/doi/abs/10.18111/wtobarometereng.2020.18.1.6 (accessed 18 October 2020).

Vahdat, A. (2020), "Iran begins lifting restrictions after brief virus lockdown”, available at: https://wcti12.com/ news/nation-world/iran-begins-lifting-restrictions-after-brief-virus-lockdown (accessed 12 April 2020).

Wen, Z., Huimin, G. and Kavanaugh, R.R. (2005), "The impacts of SARS on the consumer behavior of Chinese domestic tourists", Current Issues in Tourism, Vol. 8 No. 1, pp. 22-38.

WHO (2010), "What is a pandemic?", available at: www.who.int/csr/disease/swineflu/frequently_asked_ questions/pandemic/en (accessed 25 February 2020).

WHO (2019), "COVID-19 vaccines", available at: https:/www.who.int/emergencies/diseases/novelcoronavirus-2019/covid-19-vaccines (accessed 23 May 2021).

WHO (2020a), "COVID-19 public health emergency of international concern (PHEIC) global research and innovation forum", available at: www.who.int/publications/m/item/covid-19-public-health-emergency-ofinternational-concern-(pheic)-global-research-and-innovation-forum (accessed 12 February 2020).

WHO (2020b), "Past pandemics", available at: https://www.euro.who.int/en/health-topics/communicable\% 20diseases/influenza/pandemic-influenza/past-pandemics (accessed 17 February 2020).

WHO (2020c), "Coronavirus disease (COVID-19): vaccine access and allocation", available at: https://www. who.int/news-room/q-a-detail/coronavirus-disease-(covid-19)-vaccine-access-and-allocation (accessed 23 May 2021).

PAGE 60 J JOURNAL OF TOURISM FUTURES $\mid$ VOL. 9 NO. 12023 
WORLDOMETERS (2021), "COVID-19 coronavirus pandemic....", available at: www.worldometers.info/ coronavirus/ (accessed 9 January 2021).

Yang, Y., Zhang, H. and Chen, X. (2020), "Coronavirus pandemic and tourism: dynamic stochastic general equilibrium modeling of infectious disease outbreak", Annals of Tourism Research, Vol. 83 No. 102913.

Yu, M., Li, Z., Yu, Z., He, J. and Zhou, J. (2020), "Communication related health crisis on social media: a case of COVID-19 outbreak", Current Issues in Tourism, pp. 1-7.

Zemke, D.M.V., Neal, J., Shoemaker, S. and Kirsch, K. (2015), "Hotel cleanliness: will guests pay for enhanced disinfection?", International Journal of Contemporary Hospitality Management, Vol. 27 No. 4, pp. 690-710.

Zeng, B., Carter, R.W. and De Lacy, T. (2005), "Short-term perturbations and tourism effects: the case of SARS in China", Current Issues in Tourism, Vol. 8 No. 4, pp. 306-322.

Zheng, Y., Goh, E. and Wen, J. (2020), "The effects of misleading media reports about COVID-19 on Chinese tourists' mental health: a perspective article”, Anatolia, Vol. 31 No. 2, pp. 337-340.

\section{About the authors}

Roozbeh Mirzaei is Assistant Professor at the tourism department at the University of Mazandaran, Iran, and Visiting Professor at the University of Giessen, Germany. He has more than 10 years of experience as Consultant in tourism planning. He obtained his Ph.D. from the University of Giessen, and his research interests include consumer behavior, tourism development in protected areas, Geotourism development, tourism impacts and smart destinations. Roozbeh Mirzaei is the corresponding author and can be contacted at: r.mirzaei@umz.ac.ir

Maryam Sadin is Freelance Researcher in tourism. She holds a degree in "Tourism administration" from the department of tourism of the University of Mysore, India, and an MA in "Tourism Marketing Management" from the University of Mazandaran, Iran. Her main educational and research interests are tourism economics, marketing, tourist behavior and crisis management.

Motahareh Pedram is Freelance Researcher in tourism. She holds a degree in "Tourism administration" and an MA in "Tourism Marketing Management" from the University of Mazandaran, Iran. Her main educational and research interests are tourism economics, sustainable development, tourist behavior and tourism impacts.

For instructions on how to order reprints of this article, please visit our website: www.emeraldgrouppublishing.com/licensing/reprints.htm Or contact us for further details: permissions@emeraldinsight.com 